\title{
Fuzzy AHP Non-Additive Pada Keputusan Pendirian Klinik Bersalin Daerah
}

\author{
Awaluddin dan R. Wardoyo
}

\begin{abstract}
Abstrak- Tingginya jumlah kematian ibu dan anak menempatkan Indonesia di rangking teratas kawasan Asia Tenggara.Penelitian yang dilakukan untuk mengurangi jumlah angka kematian ibu dan anak yaitu penyedian sarana dalam hal ini klinik bersalin disuatu daerah, demi tercapainya Milenium Development Goals (MDGs) di tahun 2015.

Pengumpulan data yang mendukung penelitian ini, yaitu melakukan konsultasi dengan kepala Dinas Kesehatan Sulawesi Selatan sehingga dihasilkan kriteria-kriteria terbaik dalam pendirian klinik bersalin. Kriteria-kriteria tersebut disusun berdasarkan studi literatur, observasi, dan wawacara.Selanjutnya kriteria tersebut diberi penilaian perbandingan berpasangan dengan AHP untuk mencari bobot prior dengan skala penilaian antara 1 - 9, sedangkan untuk mencari bobot informasional dan upper excepted value menggunakan TFN (Triangular Fuzzy Number).

Hasil yang didapat dengan menggunakan Fuzzy AHP non-additive dalam pendirian klinik bersalin menunjukkan bahwa kriteria prevalensi, penduduk, kesakitan, petugas, dan sarana merupakan kriteria utama dalam pendirian klinik besalin. Metode Fuzzy AHP non-additive didalam penilaian tingkat konsistensi dilakukan pada setiap level struktur hirarki dan mampu mengakomodir ketidak konsistenan dalam penilaian.
\end{abstract}

Kata Kunci- AHP(Analitycal Hierarchy Process), non-additive, TFN (Triangular Fuzzy Number), upper excepted value.

\section{Pendahuluan}

$\mathrm{U}$ ntuk pencapaian pembangunan Millenium Development Goals (MDGs) tahun 2015 yang tujuannya menurunkan angka kematian ibu yang pada saat ini cukup tinggi yaitu dari 228 pada tahun 2010 menjadi 102 per 100.000 kelahiran hidup serta menurunkan angka kematian bayi dari 34 pada tahun 2010 menjadi 23 per. 100.000 kelahiran hidup, Dinas Kesehatan Provinsi Sulawesi Selatan mencari berbagai alternatif maupun solusi untuk pencapaian MDGs tahun 2015 tersebut.

Awaluddin, Mahasiswa S2, Jurusan Ilmu Komputer dan Elektronika, FMIPA UGM, BTN Minasa Upa Blok F11No. 14 Makassar,e-mail : awaldp@ gmail.com

Retantyo Wardoyo, Staff Pengajar Jurusan Ilmu Komputer dan Elektronika, FMIPA UGM, Yogyakarta, e-mail : rw@ugm.ac.id
Salah satu solusi yang dilakukan yaitu dengan menbangun sarana klinik bersalin, tetapi didalam membuat suatu keputusan pembangunan sarana klinik bersalin Kepala Dinas Kesehatan kadang dihadapkan pada situasi keragu-raguan apakah didaerah tersebut merupakan keputusan yang tepat dan benar membangun sarana klinik bersalin, karena data-data ataupun kriteria yang digunakan hanya berdasarkan jumlah kematian ibu dan kematian bayi, padahal diperlukan kriteria-kriteria yang lain yang dapat dijadikan pertimbangan seperti jumlah penduduk, petugas, kesakitan, dan sarana yang sudah ada, sehingga didalam menentukan suatu keputusan dalam pendirian klinik bersalin bisa tepat guna.

Tujuan dari peniltian ini adalah membuat sistem pendukung keputusan pada pendirian Klinik Bersalin diDaerah dengan metode Fuzzy AHP sebagai pemodelan DSS (Decision Support Sistem) pada keputusan didaerah mana yang tepat membangun klinik bersalin.

Manfaat penelitian ini diimplementasikan agar dapat digunakan bagi Dinas Kesehatan Provinsi Sulawesi Selatan dalam mengambil keputusan untuk mengeluarkan surat izin pada suatu Lembaga, Organisasi maupun Perorangan dalam mendirikan sebuah klinik bersalin di suatu daerah.

\section{Metode PenElitian}

\subsection{Pendukung Keputusan Terkomputerisasi}

Ada berbagai alasan mengapa sistem pendukung keputusan terkomputerisasi diperlukan, sebagai contoh :

- Kecepatan Komputasi, komputer memungkinkan para pengambil keputusan untuk melakukan banyak komputasi secara cepat dan dengan biaya randah. Keputusan berdasarkan waktu sangat kritis bagi banyak situasi, mulai dari dokter di ruang gawat darurat sampai pedagang saham dilantai bursa.

- Peningkatan/perbaikan komunikasi, Banyak kelompok dapat berkolaborasi danberkomonikasi dengan baik dengan peralatan berbasis web. 
- Peningkatan produktifitas, Membangun satu kelompok pengambil keputusan, terutama para pakar, dapat sangat mahal. Pendukung terkomputerisasi dapat mengurangi ukuran kelompok dan memungkinkan para anggotanya untuk berada di berbagai lokasiyang berbeda-beda (menghemat biaya perjalanan). Selain itu, produktifitas staff pendukung dapat ditingkatkan.

- Dukungan teknis, banyak keputusan yang melibatkan komputasi yang kompleks. Data dapat disimpan di beberapa database yang berbeda-beda dan di website di manapun di dalam organisasi dan bahkan mungkin diluar organisasi.

- $\quad$ Akses data warehouse. Data warehouse yang besar, seperti yang dioperasikan oleh wall mart, berisi petabyte data. Diperlukan metode khusus, dan kadang komputasi parallel untuk mengorganisasi dan mencari data.

- Dukungan kualitas. Komputer dapat meningkatkan kualitas keputusan yang dibuat. Sebagai contoh semakin banyak data yang diakses semakin banyak alternatif yang dapat dievaluasi.

- Berdaya saing: manajemen dan pemberdayaan sumber daya perusahaan. Tekanan persaingan membuat petugas pengambil keputusan menjadi sulit. Persaingan tidak hanya didasarkan pada harga, tetapi juga pada kualitas, kecepata, kustomisasi produk, dan dukungan pelanggan.

- Mengatasi keterbatasan Kognitif dalam pemrosesan dan penyimpanan. Menurut [1], otak manusia memiliki kemampuan yang terbatas untuk memproses dan menyimpan informasi.

\subsection{Tinjuauan Pustaka}

Mengacu pada makalah Rahardjo, J., dan Sutapa, I.N, didalam penerapan Analytical Hierarchy Process (AHP) untuk pengambilan keputusan dengan banyak kriteria yang bersifat subjektif, seringkali seorang pengambil keputusan dihadapkan pada suatu permasalahan yang sulit dalam penentuan bobot setiap kriteria. Untuk menangani kelemahan AHP ini diperlukan suatu metode yang lebih memperhatikan keberadaan kriteria-kriteria yang bersifat subjektif tersebut.Salah satu metode pendekatan yang sering dipakai adalah konsep fuzzy. Konsep fuzzy yang dipakai dalam pengembangan AHP ini adalah model Fuzzy AHP dengan pembobotan non-additive yang dikembangkan oleh [2]. Untuk memperjelas penggunaan model Fuzzy AHP, dalam makalah ini dibahas mengenai seleksi karyawan, dimana alternatif-alternatif kriteria yang ada lebih banyak bersifat subjektif. Disamping itu juga ditampilkan hasil perhitungan dengan AHP [3], dengan tujuan membandingkan hasilnya dengan Fuzzy AHP.

\subsection{Metode Fuzzy AHP Non-Additive}

Metode Fuzzy AHP dengan pembobotan nonadditive terdiri dari empat langkah, yaitu :

\section{Penentuan nilai (score) dari masing-masing} alternatif terhadap masing-masing kriteria

Pada tahap ini, pengambil keputusan diminta memberikan serangkaian penilaian terhadap alternatif $\mathrm{x}$ yang ada dalam bentuk bilangan TFN (fuzzy triangular number), yang selanjutnya nilai fuzzy tersebut didefenisikan bagi setiap alternatif pada setiap kriteria.

Untuk menentukan bobot masing-masing alternatif, ada dua metode yang biasa digunakan.Metode subjektif, yaitu pengambil keputusan menetapkan suatu nilai sebagai bobot sesuai dengan nilai-nilai yang telah disediakan.Sedangkan pada metode objektif penilaian dari pengambil keputusan tidak diperlukan, dimana nilai dari suatu alternatif berasal dari nilai intrinsik alternatif tersebut yang kemudian secara objektif diterjemahkan kedalam nilai keanggotaan melalui nilai fungsi keanggotaan.

Output dari tahap ini adalah penilaian alternatif dari pengambil keputusan yang berupa penilaian dalam bentuk variable linguistik fuzzy. Hasil dari penilaian fuzzy terhadap alternatif pada kriteria maupun subkriteria ini digunakan sebagai input didalm melakukan matrikss perbandingan berpasangan antara alternatif kriteria dan subkriteria serta mencari bobot informasional.

\section{Pembobotan kriteria dan subkriteria}

Menurut Zeleny [2], ada dua metode pendekatan untuk menentukan bobot suatu kriteria maupun subkriteria :

\section{Bobot Apriori (wi)}

Merupakan bobot yang berasal dari hasil perbandingan berpasangan AHP terhadap kriteria maupun subkriteria berdasarkan matriks Saaty, nilai yang ditetapkan secara apriori dan relatif stabil (menggambarkan keadaan psikologis dan sosial dari pengambil 
keputusan). Dimana langkah-langkah perhitungannya tersaji pada halaman berikut:

- Menentukan perbandingan berpasangan $a_{i j}=\frac{w_{i}}{w_{j}}, i j=1,2, \ldots, n$.

dimana $\mathrm{n}$ menyatakan jumlah kriteria yang dibandingkan, $W_{i}$ bobot untuk kriteria ke- $i$, dan $a_{i j}$ adalah perbandingan bobot kriteria ke- $i$ dan $j$. Jika indeks konsistensi lebih besar dari satu, maka perbandingan berpasangan harus diulang.

- Menormalkan setiap kolom dengan cara membagi setiap nilai pada kolom ke-i dan baris ke-j dengan nilai terbesar pada kolom ke-i

$a_{i j}=\frac{a_{i j}}{\max a_{i j}}, \forall i, j$

- Menjumlahkan nilai pada setiap kolom ke-i, yaitu

$$
a_{i}=\Sigma_{j} a_{i}, w
$$

- Akhirnya bobot prior bagi setiap kriteria ke-i, didapat dengan membagi setiap nilai $\hat{a} i$ dengan jumlah kriteria yang dibandingkan (n), yaitu

$$
w_{1}=\frac{\dot{s}_{2}}{n}, \forall i
$$

\section{Bobot informasional $\underline{\lambda i}$}

Bobot yang didapatkan dari tahap penilaian alternatif dalam bentuk variable linguistik fuzzy yang sifatnya konteks dependen dan relatif tidak stabil. Dalam hal ini digunakan metode entropy. Langkahlangkah perhitungannya adalah sebagai berikut:

- Defuzzyfikasi skor fuzzy pada setiap kriteria ke-I alternatif ke-j menggunakan titik berat atau centroid, yaitu

$d_{U}(x)=\frac{\sqrt{u} c(x) x d x}{\int_{-}^{c} c(x) d x}$

dimana $\quad \mathrm{C}(\mathrm{x})$ merupakan fungsi keanggotaan yang kontinu dari $\mathrm{x}$ pada himpunan fuzzy $\mathrm{C}$.

Sedangkan, untuk fungsi keanggotaan yang diskrit maka titik beratnya dirumuskan sebagai

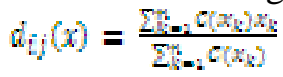

- Membentuk matrikss $i X j$ dan menormalkan $d_{\mathrm{ij}}$, dengan cara membagi nilai pada setiap kolom ke-i dengan nilai terbesar pada kolom tersebut, yakni

$d_{i j}=\frac{a_{1 j}}{\max _{j} d_{13}}, w i j$

- Menjumlahkan nilai yang telah dinormalkan pada setiap kriteria menjadi Di untuk semua I, yaitu: $g\left(d_{i}\right)=-k \sum_{j=1}^{n} \frac{d_{i j}}{D_{2}} n\left(\frac{d_{i j}}{D i}\right), i=1,2, \ldots, n$

dimana $D_{i}$ adalah total nilai untuk setiap kriteria ke-i, yaitu $D_{i}=\Sigma_{i} d_{i j}, \forall i$, konstanta pengali $k$ adalah $k=1 / \ln (n)$, dan $\mathrm{n}$ adalah jumlah kriteria yang dibandingkan.

- Menghitung bobot informasional untuk setiap kriteria ke-i, yaitu

$A_{1}=\frac{1}{n-E_{i=2} \varepsilon\left[d_{2}\right]}\left[1-o\left(d_{1}\right)\right]$

- Akhirnya, total bobot kriteria ke-I dapat dirumuskan sebagai

$\lambda_{i}=\dot{W} \bar{W} \times \lambda_{i}, i=1,2, n$

Jika nilai total bobot $\lambda i$ yang terbesar tidak mendekati satu, maka harus dinormalkan yakni

$$
\tilde{A}_{i}=\frac{\lambda_{i}}{\max _{i} \lambda_{i}}, i=1,2, \ldots, n
$$

3. Penentuan nilai akhir suatu alternatif pada level atau sublevel tertentu

Didasarkan pada non-additive measure, bilieve, dan possibility measure, dengan data input dari tahap kedua, yaitu bobot total normalisasi masing-masing kriteria. Langkahlangkah menetukan nilai akhir suatu alternatif, menurut [2]:

\section{Langkah 1 :}

Tentukan nilai possibility $\left(\eta_{i}=\chi_{i}\right)$ yang berasal dari bobot total normalisasi masingmasing kriteria, kemudian diurutkan dari yang terkecil sampai terbesar $w=\left\{r_{1}^{T}, r_{2}^{T}, \ldots, r_{n}^{T}\right\}$, dimanar $n_{i-1}^{T} \leq r_{i}^{T}, i=$ $1,2, \ldots, n$

\section{Langkah 2 :}

Menentukan himpunan lattice dari semua kriteria berdasarkan nilai possibility-nya, kemudian menentukan nilai basic assignment dari masing-masing himpunan.

$r_{1}^{T}-r_{i-1}^{T}=m\left(A_{i}\right)$

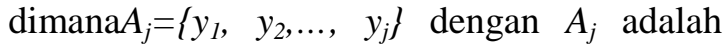
sebuah himpunan lattice dan $y_{j}$ berkorespondensi satu-satu dengan nilai possibility $r_{\mathrm{j}}$.

\section{Langkah 3 :}

Peringkat dari bilangan fuzzy didapatkan dari evaluasi setiap alternatif didasarkan pada kriteria yang berhubungan dengan nilai batas atas yang diharapkan $E^{*}$ dan nilai batas bawah yang diharapkan $E_{k}$, yaitu

$E^{*}(f)=\sum_{i=1}^{n}\left(r_{i}-r_{i-1}\right) \max _{y \in t} f(y)$
$E_{*}(f)=\sum_{i=1}^{n}\left(r_{i}-r_{i-1}\right) \max =A^{-} f(0)$

dimana $f(y)$ adalah nilai alternatif dibawah kriteria $\mathrm{x}$, dan $\mathrm{n}$ adalah jumlah kriteria. 


\section{Perangkingan atau pemilihan keputusan}

Langkah-langkah perangkingan adalah sebagai berikut :

\section{Langkah 1 :}

Misalkan terdapat $\mathrm{n}$ buah hirarki, dimana $\mathrm{n}$ $\geq 2$, maka hirarki ke-0 merupakan tujuan atau goal yang ingin dicapai dan hirarki ke-n alternatif-alternatif. Misalkan pula nilai suatu alternatif terhadap kriteria $\mathrm{ke} \mathrm{j}$ pada hirarki ke-i adalah sebagai berikut :

$f_{i j}(x)=\sum_{j} w_{i-1, j}(-1, j)$

dimana $j$ adalah indeks yang relevan terhadap banyaknya alternatif. Langkah ini dilakukan dari $i=\mathrm{n}-2$ sampai $i=0$. Saat $i=0$ tidak ada lagi kriteria ke-j yang sesuai karena tidak ada kriteria pada hierarki 0 , maka pada saat $i=0$ akan didapat nilai akhir untuk setiap kriteria, dinyatakan dengan $f(x)$, dimana nilai akhir dari $f(\mathrm{x})$ ini berupa bilangan $f u z z y$.

\section{Langkah 2 :}

Misalkan penilaian akhir dari step 3 didapatkan nilai suatu alternatif berupa TFN "X" $=(\mathrm{a}, \mathrm{b}, \mathrm{c})$ yang normal, index ratting attitude didefenisikan :

$\gamma=(\mathrm{a}-\mathrm{c}) /(\mathrm{b}-\mathrm{c})$

\section{Langkah 3 :}

Menentukan jumlah dari indeks ratting attitude $\beta$ dengan data evaluasi individual yang diperoleh dari rumus :

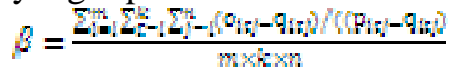

\section{Keternown:}

$m:$ Jumlah alternatif

$k$ : Jumlah pengambil keputusan

$n$ : Jumlah kriteria pada level nol

\section{Langkah 5 :}

Menghitung nilai rangking $U_{t}\left(F_{t}\right)$, Dimana $F_{t}$ merupakan nilai akhir dari alternatif ke-I dimana $\mathrm{F}_{\mathrm{t}}=\mathrm{U}_{\mathrm{t}}$.

$$
\begin{aligned}
& U_{t}=\beta\left[\left(z_{i}-x_{1}\right) /\left(x_{2}-x_{1}-Q_{i}+z_{i}\right)\right]^{+} \\
& \mathcal{1}-\beta\left[1-x_{2}-Y_{0}\right) /\left(x_{1}-x_{2}+\varphi_{1}-Y_{1}\right]
\end{aligned}
$$

\subsection{Hirarki Pendirian Klinik Bersalin}

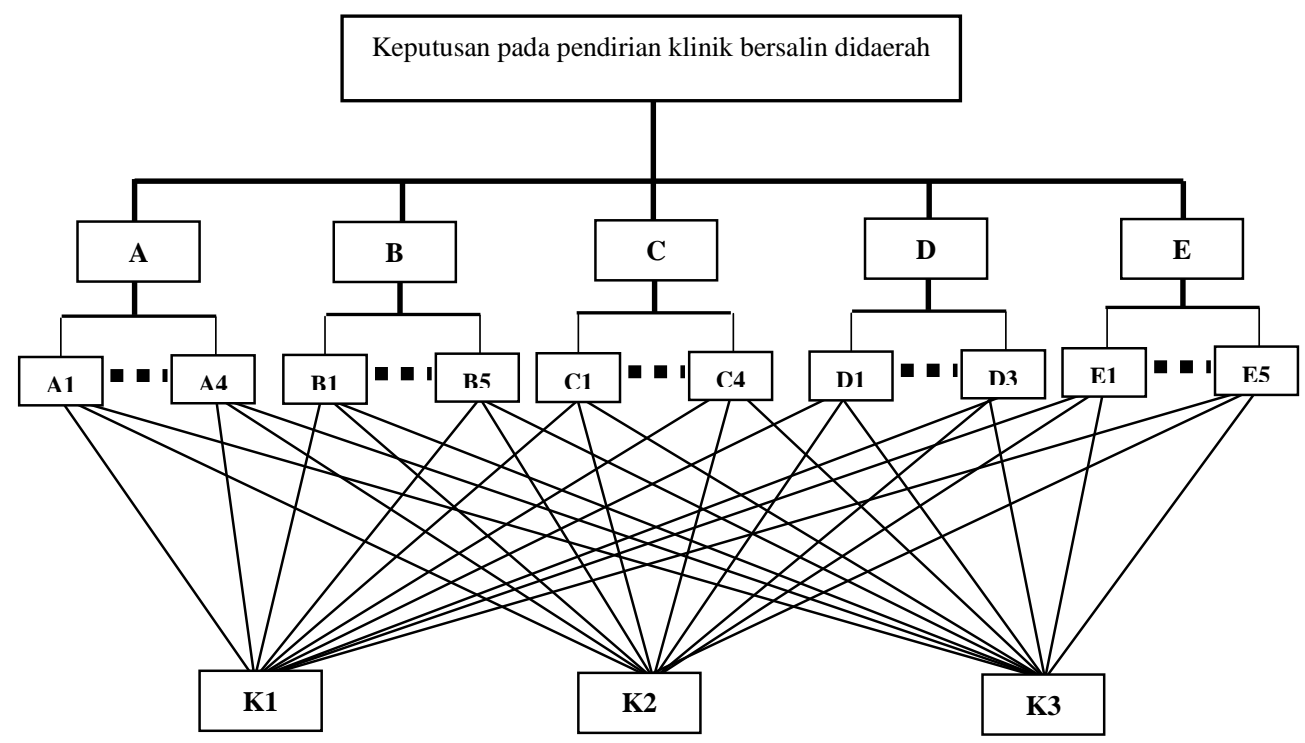

Gambar 1 Hirarki kriteria pada pendirian Klinik Bersalin didaerah

Keterangan gambar :

$\begin{array}{lll}\text { A } & : & \text { Kriteria Penduduk } \\ \text { A1 } & : & \text { Laki } \\ \text { A2 } & : & \text { Wanita } \\ \text { A3 } & : & \text { Bayi } \\ \text { A4 } & : & \text { Balita } \\ \text { B } & : & \text { Kriteria Prevalensi } \\ \text { B1 } & : & \text { Kehamilan Ibu } \\ \text { B2 } & : & \text { Kematian Ibu } \\ \text { B3 } & : & \text { Kelahiran Bayi } \\ \text { B4 } & : & \text { Kematian Bayi } \\ \text { B5 } & : & \text { Kematian Balita } \\ \text { C } & : & \text { Kriteria Kesakitan } \\ \text { C1 } & : & \text { Ibu Sebelum } \\ \text { C2 } & : & \text { Ibu Sesudah }\end{array}$

$\begin{array}{lll}\text { C3 } & : & \text { Bayi Sakit } \\ \text { C4 } & : & \text { Balita Sakit } \\ \text { D } & : & \text { Kriteria Petugas } \\ \text { D1 } & : & \text { Dokter Spesialis } \\ \text { D2 } & : & \text { Dokter Umum } \\ \text { D3 } & : & \text { Bidan } \\ \text { E } & : & \text { Kriteria Sarana } \\ \text { E1 } & : & \text { Rumah Sakit } \\ \text { E2 } & : & \text { Puskesmas } \\ \text { E3 } & : & \text { Puskesmas Pembantu } \\ \text { E4 } & : & \text { Praktek Dokter Swasta } \\ \text { E5 } & : & \text { Praktek Bidan Swasta } \\ \text { K1 } & : & \text { Kota-1 } \\ \text { K2 } & : & \text { Kota-2 } \\ \text { K3 } & : & \text { Kota-3 }\end{array}$




\section{HASIL DAN PEMBAHASAN}

Tabel 1 Hasil dari sistem informasi pendirian klinik bersalin

\begin{tabular}{l|l|l}
\hline Kota & Nilai_Akhir & Prioritas \\
\hline Pangkep & 0.898 & 1 \\
\hline Wajo & 0.898 & 2 \\
\hline Soppeng & 0.85 & 3 \\
\hline Jeneponto & 0.825 & 4 \\
\hline Toraja & 0.822 & 5 \\
\hline Bulukumba & 0.82 & 6 \\
\hline Gowa & 0.78 & 7 \\
\hline Barru & 0.78 & 8 \\
\hline Bantaeng & 0.755 & 9 \\
\hline Takalar & 0.751 & 10 \\
\hline Maros & 0.702 & 11 \\
\hline Enrekang & 0.693 & 12 \\
\hline Pinrang & 0.68 & 13 \\
\hline Palopo & 0.524 & 14 \\
\hline Selayar & 0.498 & 15 \\
\hline Bone & 0.492 & 16 \\
\hline Sidrap & 0.489 & 17 \\
\hline Makassar & 0.472 & 18 \\
\hline Sinjai & 0.434 & 19
\end{tabular}

Dengan menggunakan metode fuzzy AHP non-additive dengan banyak kriteria memberikan hasil kriteria prevalensi, penduduk, kesakitan, petugas, dan sarana secara berurutan memiliki bobot terbesar. Kriteria prevalensi menempati peringkat teratas sebagai kriteria yang diutamakan oleh Kepala Dinas Kesehatan dalam memilih Kota/ Kabupaten kota/ kabupaten untuk mendirikan klinik bersalin dan hasil yang didapatkan Kota/ Kabupaten terbaik yaitu Pankep, Wajo, Soppeng, Jeneponto, dan seterusnya.

Nilai prioritas atau urutan kepentingan terhadap suatu kriteria dapat berubah jika nilai kepentingan dirubah, misalnya jika kriteria penduduk lebih penting dari kriteria prevalensi maka perubahan prioritas akan berubah. Contoh perhitungan matriks AHP dan hasil yang didapat tersaji pada tabel 2 dan 3 .

Tabel 2 Matriks perbandingan berpasangan dengan AHP sebelum

\begin{tabular}{|c|c|c|c|c|c|}
\hline & Penduduk & Prevalensi & Kesakitan & Petugas & Sarana \\
\hline Penduduk & 1 & $1 / 3$ & 3 & 2 & 4 \\
\hline Prevalensi & 3 & 1 & 3 & 2 & 3 \\
\hline Kesakitan & $1 / 3$ & $1 / 3$ & 1 & 1 & 1 \\
\hline Petugas & $1 / 2$ & $1 / 2$ & 1 & 1 & 1 \\
\hline Sarana & $1 / 4$ & $1 / 3$ & 1 & 1 & 1 \\
\hline
\end{tabular}

Tabel 3 Hasil urutan kepentingan sebelum

\begin{tabular}{|l|r|r|r|}
\hline \multicolumn{1}{|c|}{ Level 1 } & Total Baris & \multicolumn{1}{c|}{ Bobot Awal } & \multicolumn{1}{c|}{ Bobot Akhir } \\
\hline Penduduk & 3.6667 & 0.7333 & 0.7333 \\
\hline Prevalensi & 4.7500 & 0.9500 & $\mathbf{0 . 9 5 0 0}$ \\
\hline Kesakitan & 1.5278 & 0.3056 & 0.3056 \\
\hline Petugas & 1.7500 & 0.3500 & 0.3500 \\
\hline Sarana & 1.5000 & 0.3000 & 0.3000 \\
\hline
\end{tabular}

Tabel 3 menunjukkan bahwa kriteria prevalensi menempati urutan prioritas pertama didalam menentukan pendirian klinik
bersalin.Tabel 4 dan tabel 5 menunjukkan urutan prioritas setelah terjadi perubahan kepentingan. 
Tabel 4 Matriks Perbandingan berpasangan dengan AHP setelah

\begin{tabular}{|l|r|r|r|r|r|}
\hline & \multicolumn{1}{|l|}{ Penduduk } & \multicolumn{1}{|l|}{ Prevalensi } & \multicolumn{1}{l|}{ Kesakitan } & Petugas & Sarana \\
\hline Penduduk & 1 & $\mathbf{3}$ & 3 & 2 & 4 \\
\hline Prevalensi & $\mathbf{1 / 3}$ & 1 & 3 & 2 & 3 \\
\hline Kesakitan & $1 / 3$ & $1 / 3$ & 1 & 1 & 1 \\
\hline Petugas & $1 / 2$ & $1 / 2$ & 1 & 1 & 1 \\
\hline Sarana & $1 / 4$ & $1 / 3$ & 1 & 1 & 1 \\
\hline
\end{tabular}

Tabel 5 Hasil urutan kepentingan setelah

\begin{tabular}{|l|r|r|r|}
\hline & \multicolumn{1}{|c|}{ Total Baris } & \multicolumn{1}{c|}{ Bobot Awal } & \multicolumn{1}{c|}{ Bobot Akhir } \\
\hline Penduduk & 5.0000 & 1.0000 & $\mathbf{1 . 0 0 0 0}$ \\
\hline Prevalensi & 3.4167 & 0.6833 & 0.6833 \\
\hline Kesakitan & 1.5278 & 0.3056 & 0.3056 \\
\hline Petugas & 1.7500 & 0.3500 & 0.3500 \\
\hline Sarana & 1.4444 & 0.2889 & 0.2889 \\
\hline
\end{tabular}

Perubahan urutan priotitas dapat terjadi pada semua struktur hirarki jika nilai perbandingan dirubah sesuai dengan tingkat kepentingan masing-masing kriteria maupun subkriteria. Urutan prioritas pada bobot informasional akan berubah mengikuti perubahan yang terjadi pada urutan prioritas pada matriks AHP.

Perubahan pada nilai upper excepted value pada setiap kota/ kabupatendapat merubah hasil akhir dari suatu keputusan Contoh perubahan tersaji pada tabel 6, tabel 7, tabel 8, dan tabel 9.

Tabel 6 Nilai TFN akhir masing-masing Kota/ Kabupaten sebelum merubah nilai upper excepted value.

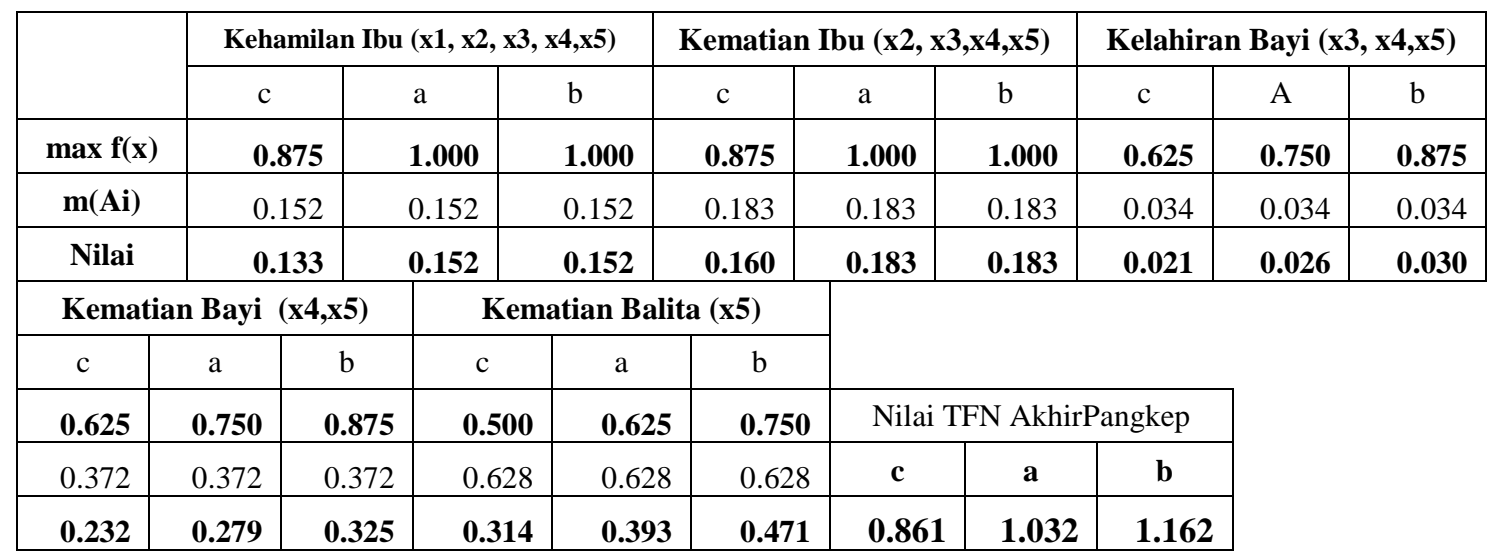

\begin{tabular}{|c|c|c|c|c|c|c|c|c|r|}
\hline & \multicolumn{4}{|c|}{ Kehamilan Ibu (x1, x2, x3, } & \multicolumn{3}{c|}{ Kematian Ibu (x2, x3,x4,x5) } & \multicolumn{3}{c|}{ Kelahiran Bayi (x3, x4,x5) } \\
\cline { 2 - 11 } & $\mathrm{c}$ & $\mathrm{a}$ & $\mathrm{b}$ & $\mathrm{c}$ & $\mathrm{a}$ & $\mathrm{b}$ & $\mathrm{c}$ & $\mathrm{A}$ & $\mathrm{b}$ \\
\hline max f(x) & $\mathbf{0 . 8 7 5}$ & $\mathbf{1 . 0 0 0}$ & $\mathbf{1 . 0 0 0}$ & $\mathbf{0 . 5 0 0}$ & $\mathbf{0 . 6 2 5}$ & $\mathbf{0 . 7 5 0}$ & $\mathbf{0 . 5 0 0}$ & $\mathbf{0 . 6 2 5}$ & $\mathbf{0 . 7 5 0}$ \\
\hline m(Ai) & 0.152 & 0.152 & 0.152 & 0.183 & 0.183 & 0.183 & 0.034 & 0.034 & 0.034 \\
\hline Nilai & 0.133 & 0.152 & 0.152 & 0.092 & 0.114 & 0.137 & 0.017 & 0.021 & 0.026 \\
\hline
\end{tabular}

\begin{tabular}{|c|c|c|c|c|c|c|c|c|}
\hline \multicolumn{3}{|c|}{ Kematian Bayi $(x 4, x 5)$} & \multicolumn{3}{|c|}{ Kematian Balita (x5) } & & & \\
\hline $\mathrm{c}$ & $\mathrm{a}$ & $\mathrm{b}$ & $\mathrm{c}$ & $\mathrm{a}$ & $\mathrm{b}$ & & & \\
\hline 0.500 & 0.625 & 0.750 & 0.375 & 0.500 & 0.625 & Nilai ' & Akhir S & \\
\hline 0.372 & 0.372 & 0.372 & 0.628 & 0.628 & 0.628 & c & $\mathbf{a}$ & b \\
\hline 0.186 & 0.232 & 0.279 & 0.236 & 0.314 & 0.393 & 0.663 & 0.834 & $\mathbf{0 . 9 8 7}$ \\
\hline
\end{tabular}




\begin{tabular}{|c|c|c|c|c|c|c|c|c|c|}
\hline & \multicolumn{4}{|c|}{ Kehamilan Ibu (x1, x2, x3, } & \multicolumn{3}{c|}{ Kematian Ibu (x2, x3,x4,x5) } & \multicolumn{3}{c|}{ Kelahiran Bayi (x3, x4,x5) } \\
\cline { 2 - 10 } & $\mathrm{c}$ & $\mathrm{a}$ & $\mathrm{b}$ & $\mathrm{c}$ & $\mathrm{a}$ & $\mathrm{b}$ & $\mathrm{c}$ & $\mathrm{a}$ & $\mathrm{b}$ \\
\hline $\max \mathbf{f}(\mathbf{x})$ & $\mathbf{0 . 6 2 5}$ & $\mathbf{0 . 7 5 0}$ & $\mathbf{0 . 8 7 5}$ & $\mathbf{0 . 6 2 5}$ & $\mathbf{0 . 7 5 0}$ & $\mathbf{0 . 8 7 5}$ & $\mathbf{0 . 5 0 0}$ & $\mathbf{0 . 6 2 5}$ & $\mathbf{0 . 7 5 0}$ \\
\hline m(Ai) & 0.152 & 0.152 & 0.152 & 0.183 & 0.183 & 0.183 & 0.034 & 0.034 & 0.034 \\
\hline Nilai & 0.095 & 0.114 & 0.133 & 0.114 & 0.137 & 0.160 & 0.017 & 0.021 & 0.026 \\
\hline
\end{tabular}

\begin{tabular}{|c|c|c|c|c|c|c|c|c|}
\hline \multicolumn{3}{|c|}{ Kematian Bayi $(x 4, x 5)$} & \multicolumn{3}{|c|}{ Kematian Balita (x5) } & & & \\
\hline $\mathrm{c}$ & $\mathrm{a}$ & b & $\mathrm{c}$ & $\mathrm{a}$ & $\mathrm{b}$ & & & \\
\hline 0.500 & 0.625 & 0.750 & 0.375 & 0.500 & 0.625 & Nilai & F Akhi & rajo \\
\hline 0.372 & 0.372 & 0.372 & 0.628 & 0.628 & 0.628 & c & $\mathbf{a}$ & b \\
\hline 0.186 & 0.232 & 0.279 & 0.236 & 0.314 & 0.393 & 0.648 & 0.819 & 0.990 \\
\hline
\end{tabular}

Tabel 7 Hasil akhir dan urutan prioritas sebelum perubahan nilai upper excepted value.

\begin{tabular}{|c|r|c|}
\hline & Nilai Akhir & Rank \\
\hline Pangkep & 1.248 & 1 \\
\hline Wajo & 1.065 & 2 \\
\hline Soppeng & 0.798 & 3 \\
\hline
\end{tabular}

Tabel 8 Nilai TFN akhir masing-masing Kota/ Kabupaten setelah merubah nilai upper excepted value

\begin{tabular}{|c|c|c|c|c|c|c|c|c|c|c|c|}
\hline & \multicolumn{5}{|c|}{$\begin{array}{c}\text { Kehamilan Ibu (x1, x2, x3, } \\
\text { x4,x5) }\end{array}$} & \multicolumn{3}{|c|}{ Kematian Ibu $(x 2, x 3, x 4, x 5)$} & \multicolumn{3}{|c|}{ Kelahiran Bayi (x3, x4,x5) } \\
\hline & \multicolumn{2}{|c|}{$\mathrm{c}$} & 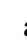 & 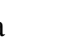 & $\mathrm{b}$ & $\mathrm{c}$ & $\mathrm{a}$ & $\mathrm{b}$ & $\mathrm{c}$ & $\mathrm{a}$ & $\mathrm{b}$ \\
\hline $\max f(x)$ & \multicolumn{2}{|c|}{0.625} & \multicolumn{2}{|c|}{0.750} & 0.875 & 0.625 & 0.750 & 0.875 & 0.500 & 0.625 & 0.750 \\
\hline $\mathbf{m}(\mathbf{A i})$ & \multicolumn{2}{|c|}{0.152} & \multicolumn{2}{|c|}{0.152} & 0.152 & 0.183 & 0.183 & 0.183 & 0.034 & 0.034 & 0.034 \\
\hline Nilai & \multicolumn{2}{|c|}{0.095} & \multicolumn{2}{|c|}{0.114} & 0.133 & 0.114 & \multirow[t]{3}{*}{0.137} & 0.160 & 0.017 & 0.021 & 0.026 \\
\hline \multicolumn{7}{|c|}{ Kematian Bayi $(x 4, x 5)$} & & & & & \\
\hline $\mathrm{c}$ & a & & & $\mathrm{c}$ & a & $\mathrm{b}$ & & & & & \\
\hline 0.500 & 0.625 & & & 0.6 & 0.75 & 0.875 & Nilai T & $\mathrm{N}$ akhir $\mathrm{J}$ & neponto & & \\
\hline 0.372 & 0.372 & & & 0.6 & 0.628 & 0.628 & $c$ & $a$ & $b$ & & \\
\hline 0.186 & 0.232 & & & 0.3 & 0.47 & 0.550 & 0.805 & 0.976 & 1.148 & & \\
\hline
\end{tabular}

\begin{tabular}{|c|c|c|c|c|c|c|c|c|c|c|c|c|}
\hline & \multicolumn{6}{|c|}{$\begin{array}{c}\text { Kehamilan Ibu (x1, x2, x3, } \\
\text { x4,x5) }\end{array}$} & \multicolumn{3}{|c|}{ Kematian Ibu $(x 2, x 3, x 4, x 5)$} & \multicolumn{3}{|c|}{ Kelahiran Bayi $(x 3, x 4, x 5)$} \\
\hline & \multicolumn{2}{|c|}{$\mathrm{c}$} & & $\mathrm{a}$ & & $\mathrm{b}$ & $\mathrm{c}$ & $\mathrm{a}$ & $\mathrm{b}$ & $\mathrm{c}$ & $\mathrm{a}$ & $\mathrm{b}$ \\
\hline $\max f(x)$ & \multicolumn{2}{|c|}{0.875} & & 1.000 & & 1.000 & 0.875 & 1.000 & 1.000 & 0.875 & 1.000 & 1.000 \\
\hline $\mathbf{m}(\mathbf{A i})$ & \multicolumn{2}{|c|}{0.152} & & 0.152 & & 0.152 & 0.183 & 0.183 & 0.183 & 0.034 & 0.034 & 0.034 \\
\hline Nilai & \multicolumn{2}{|c|}{0.133} & & 0.152 & & 0.152 & 0.160 & 0.183 & 0.183 & 0.030 & 0.034 & 0.034 \\
\hline \multicolumn{4}{|c|}{ Kematian Bayi $(x 4, x 5)$} & \multicolumn{4}{|c|}{ Kematian Balita (x5) } & & & & & \\
\hline $\mathrm{c}$ & $\mathrm{a}$ & \multicolumn{2}{|c|}{$\mathrm{b}$} & \multicolumn{2}{|c|}{$\mathrm{c}$} & $\mathrm{a}$ & $\mathrm{b}$ & & & & & \\
\hline 0.944 & 0.625 & \multicolumn{2}{|c|}{0.750} & \multicolumn{2}{|c|}{0.625} & 0.750 & 0.875 & \multicolumn{3}{|c|}{ Nilai TFN akhir Wajo } & & \\
\hline 0.372 & 0.372 & & & & & 0.628 & 0.628 & $c$ & $a$ & $b$ & & \\
\hline 0.351 & 0.232 & & & & & 0.471 & 0.550 & 1.067 & 1.073 & 1.198 & & \\
\hline
\end{tabular}




\begin{tabular}{|c|c|c|c|c|c|c|c|c|c|c|c|}
\hline & \multicolumn{5}{|c|}{$\begin{array}{c}\text { Kehamilan Ibu (x1, x2, x3, } \\
\text { x4,x5) }\end{array}$} & \multicolumn{3}{|c|}{ Kematian Ibu (x2, x3,x4,x5) } & \multicolumn{3}{|c|}{ Kelahiran Bayi (x3, x4,x5) } \\
\hline & \multicolumn{2}{|c|}{$\mathrm{c}$} & & $\mathrm{a}$ & $\mathrm{b}$ & $\mathrm{c}$ & $\mathrm{a}$ & $\mathrm{b}$ & $\mathrm{c}$ & $\mathrm{a}$ & $\mathrm{b}$ \\
\hline $\max f(x)$ & \multicolumn{2}{|c|}{0.875} & \multicolumn{2}{|c|}{1.000} & 1.000 & 0.875 & 1.000 & 1.000 & 0.875 & 1.000 & 1.000 \\
\hline $\mathbf{m}(\mathbf{A} \mathbf{i})$ & \multicolumn{2}{|c|}{0.152} & \multicolumn{2}{|c|}{0.152} & 0.152 & 0.183 & 0.183 & 0.183 & 0.034 & 0.034 & 0.034 \\
\hline Nilai & \multicolumn{2}{|c|}{0.133} & & 0.152 & 0.152 & 0.160 & 0.183 & 0.183 & 0.030 & \multirow[t]{2}{*}{0.034} & 0.034 \\
\hline \multicolumn{7}{|c|}{ Kematian Bayi $(x 4, x 5)$} & \multirow{2}{*}{$0.10 J$} & & & & \\
\hline $\mathrm{c}$ & $\mathrm{a}$ & & & $\mathrm{c}$ & $\mathrm{a}$ & $\mathrm{b}$ & & & & & \\
\hline 0.875 & 1.000 & & & 0.8 & 1.000 & 1.000 & Nilai & $\mathrm{N}$ akhir $\mathrm{S}$ & oppeng & & \\
\hline 0.372 & 0.372 & & & 0.6 & 0.628 & 0.628 & $c$ & $a$ & $b$ & & \\
\hline 0.325 & 0.372 & & & 0.5 & 0.628 & 0.628 & 1.198 & 1.369 & 1.369 & & \\
\hline
\end{tabular}

Tabel 9 Hasil akhir dan urutan prioritas setelah perubahan nilai upper excepted value.

\begin{tabular}{|c|c|c|}
\hline & Nilai Akhir & Rank \\
\hline Wajo & 1.165 & 2 \\
\hline Pangkep & 1.159 & 1 \\
\hline Soppeng & 0.793 & 3 \\
\hline
\end{tabular}

Perubahan-perubahan nilai yang terjadi pada bobot prior, bobot informasional, dan upper excepted value dapat merubah nilai akhir dan urutan prioritas pendirian klinik bersalin didaerah.

\section{KESIMPULAN}

Berdasarkan hasil perhitungan secara keseluruhan dengan menggunakan fuzzy AHP non-additive dengan kriteria prevalensi, penduduk, kesakitan, petugas, dan sarana sebagai pembentuk suatu keputusan maka didapat hasil secara berurutan Pangkep, Wajo, Soppeng, Jeneponto, Toraja, Bulukumba, Gowa, Barru, Bantaeng, Takalar, Maros, Enrekang, Pinrang, palopo, Selayar, Bone, Sidrap, Makassar, dan Sidrap dalam keputusan pendirian klinik bersalin didaerah.

Kekurangan Fuzzy AHPnon-additive tidak adanya nilai batas atas dan batas bawah didaerah mana yang paling baik mendirikan klinik bersalin.

Untuk penelitian selanjutnya, penelitian dapat dilakukan pada masalah-masalah yang lain atau masalah yang sama tetapi menggunakan pendekatan objektif atau integrasi dan didalam perhitungannya menggunakan representasi yang lain dari sistem fuzzymisalnya kurva linear, kurva trapesium, kurva $\mathrm{S}$ pertumbuhan, dan kurva $\mathrm{S}$ penyusutan dalam menentukan nilai possibility.
Untuk penelitian selanjutnya, penelitian dapat dicoba dengan lebih banyak pengambil keputusan dalam penilaian setiap kriteria dan subkriteria atau menggunakan kusioner untuk menentukan bobot dari suatu kriteria dan subkriteria didalam mencari bobot total maupun bobot informasionalnya.

\section{UCAPAN TERIMA KASIH}

Puji syukur kepada Allah S.W.T yang telah memberikan akal dan pikiran sehingga peneliti dapat menyelesaikan tesis ini, kepada ayahanda Ahmad Mauluddin (alm), ibunda Murny K, adinda Ashary, Isma Sawitri dan Annisa.

\section{DAFTAR PUSTAKA}

[1] Simon, H., 1977. The New Science of Management Decision. Englewood Cliffs, NJ: Prentice Hall.

[2] Yudhistira, T. L. D., 2000. "The Development of Fuzzy AHP using Non-Additive Weight and Fuzzy Score", INSAHP, Jakarta.

[3] Saaty, T. L., 1990, "The Analytic Hierarchy Process", McGraw-Hill", New York

[4] Septiana, A., 2006. Penentuan Alternatif Tindakan pada Sistem Pengambilan Keputusan, Tugas Akhir, Program Studi Teknik Industri, Universitas Islam Indonesia, Yogyakarta. 